新生児の麻酔ぜよ!!

\title{
食道閉鎖症 /気管食道瘻の麻酔
}

香川哲郎*

[要旨］食道閉鎖症は新生児早期に手術の適応となる先天性疾患である. その 85\%を占めるC型 における麻酔上の問題点は, 気管食道瘻(TEF)があることによる肺の換気不良および胃へのガス流 入が最も重要であり, それに加えて低出生体重や心疾患を含めた合併奇形への対応があげられる. 気管チューブの位置異常により換気不良から低酸素に陥る可能性があり, TEFの位置, 太さおよ び気管チューブ先端との関係を気管支ファイバースコープで確認する. TEFの結紮までに換気を 保ち胃へのガス流入を防ぐために低い気道内圧での換気, 気管チューブ先端の位置調整, フォガテ ィーカテーテルのTEF内への挿入などが行われる.

キーワード : 食道閉鎖症, 気管食道瘻, フォガティーカテーテル

\section{はじめに}

食道閉鎖症は新生児期に手術が必要となる新生児 疾患であり，約 $3,000 \sim 4,000$ 出生に 1 人の頻度で発 生する. A 型〜 $\mathrm{E}(\mathrm{H})$ 型の 5 型に分類され (Gross 分 類, 図 1), C 型 $(85 \%)$, 次いでA 型 $(11 \%)$ の頻度 が高い。A 型以外は気管と食道の間に瘻孔(気管食 道瘻, tracheoesophageal fistula：TEF) が存在し, 麻酔管理において特別な配慮が必要である。

出生前に診断がつく症例は約 $40 \%$ であり, 出生 後は口または鼻から入れたカテーテルが食道盲端部 以下に進まないことで診断がつく，A型では胃内ガ スは見られないが，C型ではTEFを介して胃内へ ガスが流入し腸管内ガスが見られ(図2), それに伴 い胃内容の気管への流入や胃の膨満に伴う呼吸障害 が見られる。食道閉鎖症は $50 \%$ 以上に他の奇形を 伴い，心血管奇形，他の消化管奇形，染色体異常，
VACTER連合(Vertebral anomaly, Anal atresia, Cardiac malformations, Tracheoesophageal fistula, Esophageal atresia, Radial and/or renal dysplasia)などが見られる。手術治療として，C型 では上下食道のギャップが大きくなく，他に合併症 を伴わない場合は一期的根治術として TEFの切離 と上下食道吻合が行われる。一期的に行うことが適 切でない場合はこれらが段階的に行われる。また A 型では上下食道のギャップが大きいことが多く，胃 瘦造設術がまず行われ，その後，食道延長術などを 行ったのちに上下食道の吻合が行われる。

食道閉鎖症はこのように病型のみならず合併奇 形，上下食道のギャップ，さらに体重や全身状態な どさまざまな因子が術式やその後の治療方針に影響 を及ぼし，バリエーションが多い。管理法もさまざ まであり ${ }^{1)}$ ，食道閉鎖症の麻酔管理をどのように行 うことが適切かについての高いレベルのエビデンス 


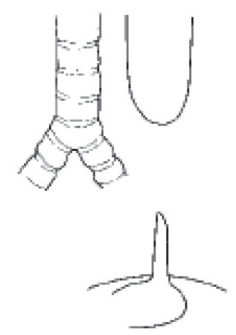

A

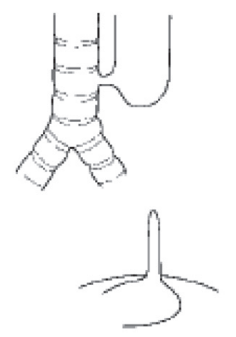

B

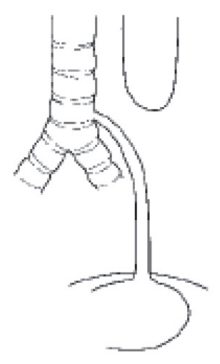

C

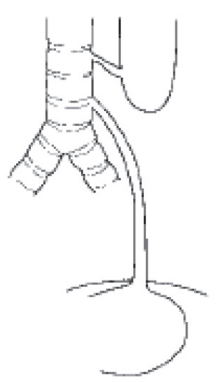

D

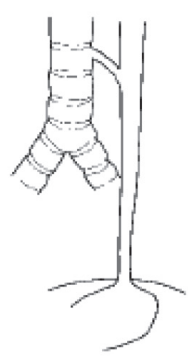

$\mathrm{E}$

図1 Gross 分類
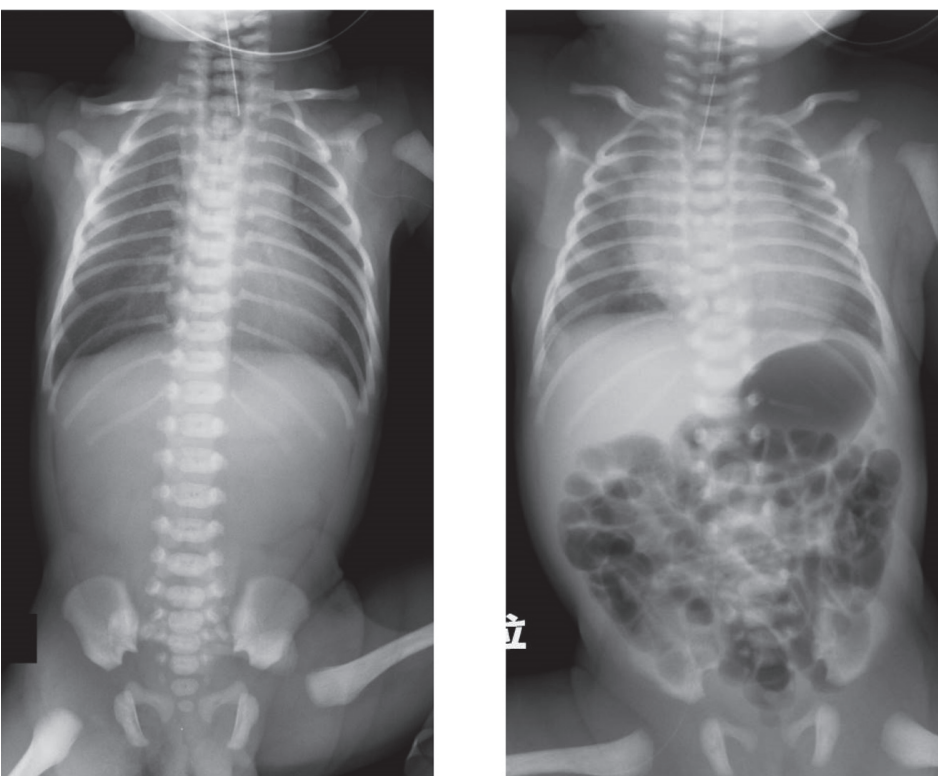

図2 食道閉鎖症のX線写真

左：A型，右：C型

いずれも胃管は上部食道までしか入っていない。

は少ない2 ため，本論文では主に C 型食道閉鎖症の 麻酔について, 教科書 ${ }^{3)}$ や文献 ${ }^{1)}{ }^{2)}$ (4) および筆者らの 施設での経験をもとに解説する。

\section{C 型食道閉鎖症の麻酔導入}

C 型食道閉鎖症における麻酔上の問題点は，TEF があることによる肺の換気不良および胃へのガス流 入が最も重要であり，それに加えて低出生体重や心 

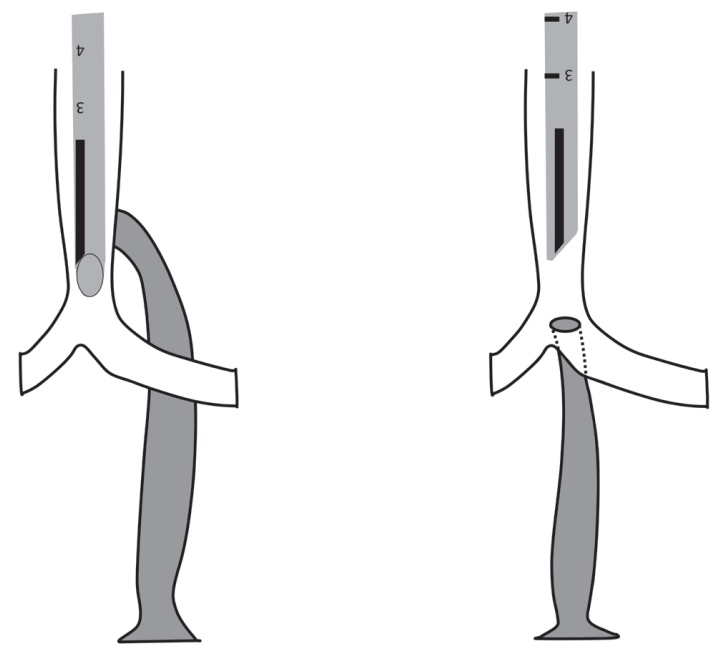

図3 TEFの位置と胃へのガス流入

左：TEF は分岐部より上にあり, 気管チューブの側 面でブロックされる(実際にはTEFは気管の背 側にあるため, 気管チューブのベベルを腹側に 向けることでより効果的にブロックできる).

右：TEFが分岐部近くだと胃へのガス流入を止めら れない.

ニズムで発生している.

この胃へのガス流入の程度は気道内圧，気管チュ ーブ先端位置, TEFの位置や太さ，肺のコンプラ イアンス等によって変化する. 挿管, 人工呼吸, あ るいは麻酔の導入において陽圧換気が必要となる が，陽圧換気により胃へのガス流入のリスクは高ま る。自発呼吸を保つことができれば，陽圧は最低限 でよく，胃へのガス流入は少なくできる。太い TEFであるほど，TEFを通した胃へのガス流入が 多くなる。また早産児, 低出生体重児や肺炎を併発 する場合などでは肺のコンプライアンスが低く，高 い気道内圧が必要となるため, 胃へのガス流入が多 くなる可能性がある.

TEF の位置と，気管チューブの先端の位置の関 係は重要である(図3)。TEFが気管分岐部よりも十 分上にあり，気管チューブの側面でTEFが塞がれ ている状態では，TEFを通したガス流入は少ない。 しかし TEFの位置は，気管分岐部およびその上 $1 \mathrm{~cm}$ 以内が $22 \%$ ，気管分岐部より下が $11 \%$ との報
告があり ${ }^{5)}$, 約 $1 / 3$ の症例では気管チューブ先端よ りも TEFは下にあることになる。また，TEFがど こにあっても，気管チューブの先端がTEFに入っ ていくことが起こりうる。すなわち瘻孔に気管チュ ーブが入って換気される状態であり，この状態では 肺は換気されない一方で胃にガスを押し込むことに なり，非常に危険な状態となる。特にTEFが太い 場合，気管チューブは容易に瘻孔に入っていく可能 性がある。

食道閉鎖症患児の麻酔導入は，上記の点を考慮し て慎重に行う。TEFの太さや位置に関する情報は, 術前のCTや気管支ファイバースコープ(以下，フ アイバー)により得られるが，これらの検査は行わ れないことも多い。こうした情報がなく，かつ術前 に挿管されていない場合の麻酔導入は，(1)可能であ れば自発呼吸を保つ，(2)陽圧換気を行う場合は低圧 で行う, (3)気管チューブの深さは, 最初は浅めとし, その後はファイバーで速やかに TEFの位置を確認 し，気管チューブ先端を適切な位置に置く，(4)緊急 時の対応として，緊急開胸による TEF 結禁もしく は開腹による下部食道バンディングをいつでも行え るよう，外科医に待機してもらう，といった方法が 取られる。筆者らは，新生児の抻管から $\mathrm{TEF}$ 離断 に至るまでの間に自発呼吸を保つ方法は必ずしも容 易ではないことを考慮し，多くの場合で陽圧換気を 容認する方法を選択している。口腔内・上部食道内 を十分吸引し，硫酸アトロピン $0.1 \mathrm{mg}$ を投与したの ち，セボフルランによる緩徐導入，もしくはチオぺ ンタールによる急速導入で入眠させ，ロクロニウム を投与，低圧 $\left(\sim 10 \mathrm{cmH}_{2} \mathrm{O}\right.$ 程度以下 $)$ でマスク換気 を行い，挿管を行っている．ファイバーでTEFの 位置を確認し，気管チューブ先端を TEF 開口部よ りも遠位に置くことができればそのようにする。 TEF 開口部が気管分岐部付近もしくはそれより遠 位にある場合は，気管チューブ先端は気管中部とし ておく。自発呼吸を保つ場合は，セボフルラン（ $3 \%$ 程度)またはミダゾラム $(0.05 \sim 0.1 \mathrm{mg} / \mathrm{kg}$ ずつ夕 
イトレーション), フェンタニル $(0.5 \sim 1.0 \mu \mathrm{g} / \mathrm{kg}$ ず つタイトレーション)により導入し, 低圧で補助呼 吸を加えつつ挿管に至るようにしている。

術式は, 左側臥位, 右開胸あるいは胸腔鏡下に TEF 切離が行われ, それに続いて可能であれば上 下食道の一期的吻合が行われる。上下食道のギャッ プが大きい場合は食道の吻合は行わず，胃瘻を造設 する.右側大動脈弓がある場合は左開胸で行われる.

\section{II＼cjkstart麻酔の維持とガス流入を防ぐ方法}

麻酔の維持においても, TEFが離断されるまで は，TEFを通して胃へガスが流入することを避け る必要がある. TEF 離断後は通常の陽圧換気を行 うことができる，食道吻合後は胃管を通してステン トとする。術後は吻合部の安静のため挿管, 鎮静の 状態で州室する場合が多いが，症例によっては早期 抜管も可能と考えられる ${ }^{6}$. 抜管後の喉頭展開, 再 挿管は吻合部にストレスがかかることや食道扦管の 危険性があるため，極力避けるべきである。

TEF離断までに胃へのガス流入を防ぐ方法とし て, 以下の 3 方法と, 後述するバルーン付きカテー テルによる閉塞を行う方法がある ${ }^{2}$.

1. 低い気道内压による換気を行う：TEFよりも上 に気管チューブ先端がある場合に用いられる方法 である.自発呼吸に低压の補助呼吸を加えた換気, もしくは調節呼吸で気道内圧を低く保つ。ファイ バーにて TEFが細いとわかれば，ある程度気道 内压を上げることは可能である。TEFが太い場 合や肺のコンプライアンスが低い場合は，十分な 換気が行えないことによる高炭酸ガス血症，低酸 素血症を許容せざるを得ないため, できるだけ早 く TEF 離断を行ってもらうよう外科医に依頼す る.

2. 気管チューブ側面で TEFを塞ぐ：TEFが気管分 岐部よりも上にあり，ある程度以上の距離があれ ば，この方法は比較的容易である。マーフィ孔の ない気管チューブを使用する。カフ付き気管チュ
ーブを用いて，カフ部分で TEFを閉塞すること ができればより確実であり，Microcuff小児用気 管チューブのようなカフ位置が先端に近い製品は 有用である可能性が高い。気管チューブの位置の 移動によって，TEFに気管チューブ先端が入る 可能性や，気管支挿管になる可能性がある。

3. 左主気管支挿管を行う：気管チューブの中にファ イバーを通し，左主気管支内に誘導する。TEF はブロックされ，右肺は換気されないので手術に 都合がよい，左主気管支は気管よりも若干細いた め ${ }^{7)}$, 初めから細めの気管チューブを選択する必 要があるかもしれない。気管チューブ先端を主気 管支の中の適切な場所に保つことは難しく，浅く なると両肺換気になり，深くなると気管支の損傷 や，左上葉枝のブロックの可能性がある.

\section{III バルーン付きカテーテルによるガス流入予防}

筆者らの経験では，気管チューブ先端がTEFよ り上にある場合，術中に高炭酸ガス血症，低酸素血 症をきたすことがしばしばあった。また，気管チュ ーブ先端がTEF内に入ったことによると考えられ る高度低酸素・心停止をきたしたこともあった。こ うしたことから，筆者らは2011年からフォガティ ーカテーテル(以下，Fogarty）による TEFの閉塞 を，可能な症例には行ってきた ${ }^{8)}$. Fogarty を適切 に留置できた後は通常の呼吸管理を行うことがで き，血液ガスの正常化や誤嶼防止の面などから利点 は大きい。 また外科医にとってはFogartyによって TEF を認識しやすくなるため都合がよい.

筆者らが通常行っている Fogartyの留置方法は, 前述の方法で入眠させたのち, (1) Fogartyの $3 \mathrm{Fr}$ (も しくは $4 \mathrm{Fr}$ )を経口的に挿入, (2)内径 $2.5 \mathrm{~mm}$ もしく は3.0mmの気管チューブを挿管, (3)気管チューブ の中にファイバーを進め，観察しながら Fogartyを 動かしてTEF内に進める, (4)Fogartyのバルーン 部分が見えなくなるまで挿入したのち，規定量の空 気を入れてバルーンを膨らませる，という手順で行 


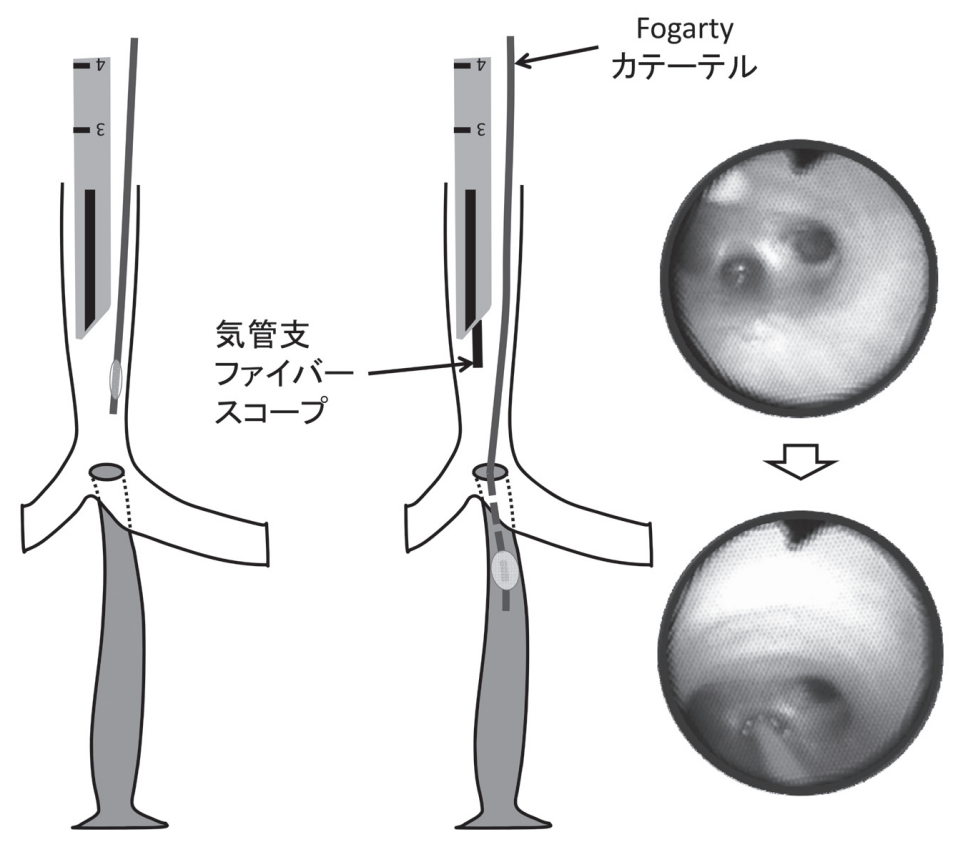

図4 Fogartyの留置

左：口から気管にFogartyを挿入後，気管チューブを挿管.

右：気管支ファイバーで見ながら Fogarty t TEF 内に進める.

つている(図4)。この方法ではFogarty は気管チュ ーブの外側にあり，それぞれの外径の和が患児の気 管サイズに適したものである必要があるが，体重 2,000〜3,000gの患児では Fogarty 3Fr (外径 $1 \mathrm{~mm}$ ) および内径 $2.5 \mathrm{~mm}$ (外径 $3.5 \mathrm{~mm}$ )もしくは $3.0 \mathrm{~mm}$ (外 径 $4.2 \mathrm{~mm}$ )の気管チューブを気管に挿入することが できている。筆者らの経験では，特に TEFが太い 場合，Fogartyの挿入はそれほど難しいものではな いが，外科医が経気管的に硬性気管支鏡を用いて， もしくは胃瘻から挿入することも可能である ${ }^{9)}$. Fogarty 扦入後は通常の呼吸管理を行い, TEFテーピ ング後はFogartyを気管の中まで抜き, TEFを離 断する。気管からすべて抜いてしまうと気管チュー ブ周囲のリークが増えて換気不良となる可能性があ る.

本法は1980年代から行われており ${ }^{10)}$ ，最近のレ ビュー ${ }^{2)}$ にも詳細の記載があるが，手技が煩雑であ り，低酸素や気道損傷のリスクを考慮すると実際的

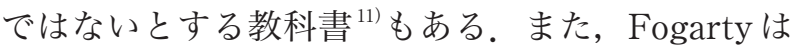
血栓除去用のカテーテルであり TEF 閉塞は目的外 使用となることから，適応を十分検討し，患者への 説明と同意を得たのちに行うべきである．胃へのガ ス流入のリスクが高い症例，すなわち TEFが太い 症例，TEFが気管分岐部近くにある症例，肺のコ ンプライアンスが低い症例，はよい適応と考えられ る. Andropoulos ら ${ }^{4)}$ は TEFの径が $3 \mathrm{~mm}$ 以上の症 例ではFogartyの留置は有用である一方，3mm未 満の症例では必要としなかったと述べており, TEFが細い症例ではFogartyの必要性は小さいと 考えられる。

\section{Fogartyについて知っておく}

FogartyによるTEF閉塞を行うにあたつては, Fogartyについてよく知っておくことも重要である. 本目的で新生児に対して用いる Fogarty は表1にあ るようなサイズがあるが，Fogartyを気管に挿入す 
表 1 Fogartyの規格

\begin{tabular}{ccccc}
\hline サイズ & 色 & スタイレット & $\begin{array}{c}\text { ガス容量 } \\
(\mathrm{mL})\end{array}$ & $\begin{array}{c}\text { バルーン径 } \\
(\mathrm{mm})\end{array}$ \\
\hline $2 \mathrm{Fr}$ & 灰 & なし & 0.2 & 4 \\
$3 \mathrm{Fr}$ & 緑 & あり & 0.6 & 5 \\
$4 \mathrm{Fr}$ & 桃 & あり & 1.7 & 9 \\
\hline
\end{tabular}

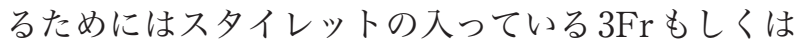
4Frが適切であると考えている. スタイレットの先 を少し曲げることで思った方向に進めることができ る. Fogartyを気管内に置いた状態で，ファイバー でTEFの位置を見た上で，スタイレットのみを抜 き，先端の角度を調整してから再度挿入することも 可能である. Fogarty はエアーを入れていくとある 点で一気に膨らみ, inflate と deflateの中間の大き さを作ることは困難である。エアーが多すぎると容 易に破裂することや，バルーンの径は決まっている ことを理解し, 患者に使用する前にエアーの量とバ ルーンの大きさを確認しておくとよい.

\section{$\mathrm{V}$ 胸腔鏡下手術の場合}

本手術を胸腔鏡下に行うことが，一部の施設で行

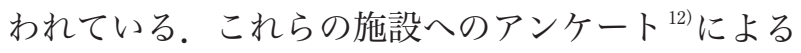
と, 安全に施行は可能であるが施設ごとに手術手技, 手術時間，管理法などにばらつきが多いとされた.

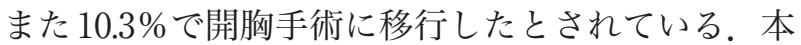
術式では胸腔に手術のためのスペースを作るため に, 術野で右胸腔へ炭酸ガスを送気して人工気胸と する，あるいは左主気管支挿管とする方法が取られ る. Fogartyは TEFに挿入する報告 ${ }^{13)}$ や，左主気 管支に挿入する報告 ${ }^{14}$ が見られる。胸腔鏡下の方が 術中の高炭酸ガス血症, 呼吸性アシドーシスの頻度 が多いとする報告 ${ }^{14)}$ からは，呼吸管理により難渋す る可能性があり, 術者との協議や綿密な計画が必要 である。

\section{おわりに}

日本小児外科学会の 2013 年の新生児症例全国集 計調査 ${ }^{15}$ によると，食道閉鎖症は年間 187 例，うち $\mathrm{C}$ 型は 170 例となっており, 一施設当たりの症例数 は限られたものである。本症はこのように症例数が 少ない一方で，バリエーションが多く，特殊な呼吸 管理が必要であり，各麻酔科医が経験值を高めるこ とは難しい。呼吸管理のほか, 鎮痛法についてもオ ピオイドの他に仙骨ブロック，傍脊椎ブロックなど さまざまな方法が用いられている ${ }^{1)}$. 受け入れ施設 の集約化や多施設によるデー夕集積により，エビデ ンスの構築やガイドラインが作成されることを期待 したい.

\section{参考文献}

1) Knottenbelt G, Costi D, Stephens P, et al. : An audit of anesthetic management and complications of tracheoesophageal fistula and esophageal atresia repair. Paediatr Anaesth 22 : 268-274, 2012

2) Ho AM, Dion JM, Wong JC : Airway and ventilatory management options in congenital tracheoesophageal fistula repair. J Cardiothorac Vasc Anesth $30: 515-520$, 2016

3) Hammer GB : Anesthesia for thoracic surgery, A Practice of Anesthesia for Infants and Children, 5th ed. Edited by Coté CJ, Lerman J, Anderson BJ. Elsevier Saunders, Philadelphia, 2013, 277-290

4) Andropoulos DB, Rowe RW, Betts JM : Anaesthetic and surgical airway management during tracheo-oesophageal fistula repair. Paediatr Anaesth $8: 313-319$, 1998

5) Holzki J : Bronchoscopic findings and treatment in congenital tracheo-oesophageal fistula. Paediatr Anaesth $2: 297-303,1992$

6）中原康雄，岩村喜信，新居章ほか：Gross C 型先天性食 道閉鎖症術後の鎮静・筋弛緩による管理は必要か? 日小外会誌 49：1096-1100, 2013

7) Hammer GB, Fitzmaurice BG, Brodsky JB : Methods for single-lung ventilation in pediatric patients. Anesth Analg 89 : 1426-1429, 1999

8）古賀聡人, 似内久美子, 末田彩ほか：Fogarty カテーテ ルを用いたC型食道閉鎖症の麻酔管理. 日臨麻会誌 
32 : S269, 2012

9）土居ゆみ, 高辻小枝子, 法華真衣ほか：局所麻酔下に造 設した胃瘦から逆行性に気管食道瘻へカテーテルを挿 入した後に全身麻酔を導入したC型食道閉鎖の一症例. 日小児麻酔会誌 $21 ： 212-216,2015$

10) Filston HC, Chitwood WR Jr, Schkolne B, et al. : The Fogarty balloon catheter as an aid to management of the infant with esophageal atresia and tracheoesophageal fistula complicated by severe RDS or pneumonia. J Pediatr Surg 17 : 149-151, 1982

11) Brett CM, Davis PJ : Anesthesia for general surgery in the neonate, Smith's Anesthesia for Infants and Children, 9th ed. Edited by Davis PJ, Cladis FP. Elsevier, Philadelphia, 2017, 571-616

12）奥山宏臣, 古賀寛之, 石丸哲也ほか：〔新生児 - 乳児領
域における内視鏡手術の展開]本邦における胸腔鏡下 食道閉鎖症手術の現況一多施設からのアンケート結果 より一. 日周産期・新生児会誌 $51: 6-8,2015$

13）漆原直人，福本弘二，三宅啓ほか：C型食道閉鎖症に対 する胸腔鏡下食道閉鎖根治術．小览外科 45：538-545, 2013

14）松成泰典, 木内恵子, 小野理恵ほか：C型食道閉鎖の新 生児に対する胸腔鏡下根治術の麻酔 : 開胸術との比較. 麻酔 59 : 1234-1240, 2010

15）日本小児外科学会学術 - 先進医療検討委員会 : わが国 の新生児外科の現状一 2013 年新生児外科全国集計一. 日小外会誌 $51: 1234-1245,2015$

16）鈴木毅：新生児期からの腹部手術・消化管手術の麻酔, 臨床小児麻酔ハンドブック (改訂第 3 版). 前川信博監修. 診断と治療社, 東京, 2013, 159

\title{
Anesthesia for Esophageal Atresia / Tracheoesophageal Fistula
}

\author{
Tetsuro KAGAWA
}

Department of Anesthesiology, Hyogo Prefectural Kobe Children's Hospital

\begin{abstract}
Esophageal atresia is a congenital anomaly which requires surgical treatment in the early neonatal period. Ventilation difficulties of the lung and insufflation of the stomach due to tracheoesophageal fistula (TEF) are the most important anesthetic problems in type-C esophageal atresia, which accounts for $85 \%$ of cases. In addition, low birth weight and comorbidities of the patient should be taken into consideration. It is necessary to confirm the location and size of TEF as well as the relationship between tracheal tube tip and TEF using fiberoptic bronchoscope because the dislocation of the tracheal tube tip may cause ventilation insufficiency and hypoxia. Techniques such as ventilation with low airway pressure, adjustments of tracheal tube tip and insertion of Fogarty catheter into the TEF are used to maintain adequate ventilation and to avoid gastric insufflation until TEF ligation.
\end{abstract}

Key Words : Esophageal atresia, Tracheoesophageal fistula, Fogarty catheter 